\title{
Phase equilibria, crystal structure and oxygen content of intermediate phases in the $\mathrm{Y}-\mathrm{Ba}-\mathrm{Co}-\mathrm{O}$ system
}

\author{
A.S. Urusova, V.A. Cherepanov*, T.V. Aksenova, L.Ya. Gavrilova, E.A. Kiselev \\ Department of Chemistry, Institute of Natural Sciences, Ural Federal University, Yekaterinburg, Russia
}

\section{A R T I C L E I N F O}

\section{Article history:}

Received 2 February 2013

Received in revised form

13 March 2013

Accepted 14 March 2013

Available online 22 March 2013

\section{Keywords:}

Synthesis

Crystal structure

Oxygen content

Thermal expansion

Phase diagram

\begin{abstract}
A B S T R A C T
The phase equilibria in the $\mathrm{Y}-\mathrm{Ba}-\mathrm{Co}-\mathrm{O}$ system were systematically studied at $1373 \mathrm{~K}$ in air. The intermediate phases formed in the $\mathrm{Y}-\mathrm{Ba}-\mathrm{Co}-\mathrm{O}$ system at $1373 \mathrm{~K}$ in air were: $\mathrm{YBaCo}_{2} \mathrm{O}_{5}+\delta, \mathrm{YBaCo}_{4} \mathrm{O}_{7}$ and $\mathrm{BaCo}_{1-y} \mathrm{Y}_{y} \mathrm{O}_{3-\delta}(0.09 \leq y \leq 0.42)$. It was shown that $\mathrm{YBaCo}_{2} \mathrm{O}_{5+\delta}$ possesses tetragonal structure with the $3 a_{p} \times 3 a_{p} \times 2 a_{p}$ superstructure (sp. gr. P4/mmm). High-temperature X-ray diffraction analysis of the $\mathrm{YBaCo}_{2} \mathrm{O}_{5+\delta}$ in the temperature range from $298 \mathrm{~K}$ up to $1073 \mathrm{~K}$ under $\mathrm{Po}_{2}=0.21$ atm has not shown any phase transformations. The value of oxygen content for the $\mathrm{YBaCO}_{2} \mathrm{O}_{5+\delta}$ at room temperature was estimated as 5.40 and at $1323 \mathrm{~K}$ it was equal to 5.04 . Thermal expansion of sample shows a linear characteristics and the average thermal expansion coefficient (TEC) is about $13.8 \times 10^{-6}$, $\mathrm{K}^{-1}$ in the temperature range $298-1273 \mathrm{~K}$. The homogeneity range and crystal structure of the $\mathrm{BaCo}_{1-y} \mathrm{Y}_{y} \mathrm{O}_{3-\delta}$ $(0.09 \leq y \leq 0.42)$ solid solutions were determined by X-ray diffraction of quenched samples. All Ba$\mathrm{Co}_{1-y} \mathrm{Y}_{y} \mathrm{O}_{3-\delta}$ solid solutions were found to have cubic structure (sp. gr. Pm3m). The unit cell parameters were refined using Rietveld full-profile analysis. Oxygen nonstoichiometry of $\mathrm{BaCo}_{1-y} \mathrm{Y}_{y} \mathrm{O}_{3-\delta}$ solid solutions with $0.1 \leq y \leq 0.4$ was measured by means of thermogravimetric technique within the temperature range $298-1373 \mathrm{~K}$ in air. Thermal expansion of $\mathrm{BaCo}_{1-y} \mathrm{Y}_{y} \mathrm{O}_{3-\delta}(y=0.0 ; 0.1 ; 0.2 ; 0.3)$ samples was studied within the temperature range $298-1200 \mathrm{~K}$ in air. The projection of isothermal-isobaric phase diagram for the $\mathrm{Y}-\mathrm{Ba}-\mathrm{Co}-\mathrm{O}$ system to the compositional triangle of metallic components was presented.
\end{abstract}

(c) 2013 Elsevier Inc. All rights reserved.

\section{Introduction}

The family of $\mathrm{LnBaCO}_{2} \mathrm{O}_{5+\delta}$ so-called double perovskites, in particular with $\mathrm{Ln}=\mathrm{Y}$, was intensively studied during last decade since they exhibit a set of properties such as high values of mixed electronic-ionic conductivity and oxygen mobility [1,2] that allows considering them as the promising cathode materials for the SOFCs [3]. Another representative of the $\mathrm{Y}-\mathrm{Ba}-\mathrm{Co}-\mathrm{O}$ system that attracts attention of many researchers is $\mathrm{YBaCo}_{4} \mathrm{O}_{7+\delta}$ [4-7]. Although a number of papers were devoted to the structure and physicochemical properties of $\mathrm{LnBaCO}_{2} \mathrm{O}_{5+\delta}$ and $\mathrm{YBaCo}_{4} \mathrm{O}_{7+\delta}$, including the crystal structure and oxygen content [1-11] the information about phase equilibria in the $\mathrm{YBa}-\mathrm{Co}-\mathrm{O}$ system is absent. The only data that can be found has concern the phase formation in the quasibinary $\mathrm{Y}-\mathrm{Co}-\mathrm{O}, \mathrm{Y}-\mathrm{Ba}-\mathrm{O}$ and $\mathrm{Ba}-\mathrm{Co}-\mathrm{O}$ systems.

\subsection{Y-Co-O system}

Only one complex oxide $\mathrm{YCoO}_{3-\delta}$ was reported in the $\mathrm{Y}-\mathrm{Co}-\mathrm{O}$ system. It was prepared by standard ceramic technique under high (50-70 kbar) oxygen pressure [12], or at $1173 \mathrm{~K}$ during $100 \mathrm{~h}$ in the oxygen flow [13-15], or by the decomposition of yttrium and cobalt cyanides [16], or by sol-gel method $[17,18]$. According to Xray diffraction it was found that after $120 \mathrm{~h}$ annealing at $1173 \mathrm{~K}$ in air $\mathrm{YCOO}_{3-\delta}$ possesses orthorhombically distorted perovskite structure (sp.gr. Pbnm) [13-18]. The unit cell parameters presented by Jadhao et al. $a=5.132 \AA$, $b=5.417 \AA$, $c=7.367 \AA ̊$ [16], were in good agreement with the data reported in $[12,14,15]$. According to Demazeau et al. [12] yttrium cobaltate $\mathrm{YCoO}_{3-\delta}$ decomposes in air at temperature higher $1123 \mathrm{~K}$, however synthesis conditions used in [13-15] make it possible to conclude that decomposition temperature probably exceeds $1173 \mathrm{~K}$.

\section{2. $Y-B a-O$ system}

The phase diagram of the $\mathrm{BaO}-\mathrm{Y}_{2} \mathrm{O}_{3}$ system in air has been studied by Lopato et al. [19], Kwestroo et al. [20] and Kovba et al. [21]. A number of ternary oxides were described in the system:

\footnotetext{
* Corresponding author. Fax: +7 3432615978.

E-mail addresses: vladimir.cherepanov@usu.ru, vl_cherepanov@mail.ru (V.A. Cherepanov).
} 
$\mathrm{Y}_{2} \mathrm{BaO}_{4}$ [19-21], $\mathrm{Y}_{4} \mathrm{Ba}_{3} \mathrm{O}_{9}$ [19,20], $\mathrm{Y}_{2} \mathrm{Ba}_{2} \mathrm{O}_{5}\left(\mathrm{Y}_{3} \mathrm{Ba}_{3} \mathrm{O}_{7.5}\right)$ [20,21], $\mathrm{Ba}_{4} \mathrm{Y}_{2} \mathrm{O}_{7}[20,21]$.

All authors found the existence of the $\mathrm{Y}_{2} \mathrm{BaO}_{4}$ from at least $900^{\circ} \mathrm{C}[20,21]$ up to its solid state decomposition to the $\mathrm{Y}_{4} \mathrm{Ba}_{3} \mathrm{O}_{9}$ and $\mathrm{Y}_{2} \mathrm{O}_{3}$ at temperature about $1400^{\circ} \mathrm{C}[19,21]$. The $\mathrm{Y}_{4} \mathrm{Ba}_{3} \mathrm{O}_{9}$ was reported to be stable from $1060{ }^{\circ} \mathrm{C}$ [21] up to its melting point at $2160^{\circ} \mathrm{C}$ [19]. The thermal stability of the phase that is written as $\mathrm{Y}_{2} \mathrm{Ba}_{2} \mathrm{O}_{5}$ [20] or $\mathrm{Y}_{3} \mathrm{Ba}_{3} \mathrm{O}_{7.5}$ [21] has not exceeded $1040^{\circ} \mathrm{C}$. Ternary oxide with the formula $\mathrm{Ba}_{4} \mathrm{Y}_{2} \mathrm{O}_{7}$ was found to be stable in the relatively narrow temperature range $1020-1140^{\circ} \mathrm{C}$ [21]. This result do not agree with the data reported by Kwestroo et al. [20] that $\mathrm{Ba}_{4} \mathrm{Y}_{2} \mathrm{O}_{7}$ had formed at $900^{\circ} \mathrm{C}$, and started to decompose at temperature above $1000^{\circ} \mathrm{C}$ to the $\mathrm{Y}_{4} \mathrm{Ba}_{3} \mathrm{O}_{9}$ and $\mathrm{BaO}$. It was also mentioned that the stability of all phases in the $\mathrm{BaO}-\mathrm{Y}_{2} \mathrm{O}_{3}$ system in the moist atmosphere is very poor and all of them decomposed immediately (except $\mathrm{Y}_{2} \mathrm{BaO}_{4}$ ) in moist air [20].

\subsection{Ba-Co-O system}

Two complex oxides $\mathrm{Ba}_{2} \mathrm{CoO}_{4}$ and $\mathrm{BaCoO}_{3-\delta}$ [22-29] were described in the $\mathrm{Ba}-\mathrm{Co}-\mathrm{O}$ system at $1100^{\circ} \mathrm{C}$ in air. Barium cobaltate $\mathrm{BaCoO}_{3-\delta}$, synthesized by traditional ceramic method [22-27], or citrate-nitrate route [28] within the temperature range $600-1000^{\circ} \mathrm{C}$ in air possesses hexagonal layered structure (sp. gr. $\left.P 6_{3} / m m c\right)$. The alternation of layers along c-axis and oxygen content of $\mathrm{BaCoO}_{3-\delta}$ strongly depend on the temperature and oxygen pressure used for preparation. Low temperature hexagonal $(2 \mathrm{H})$ structure [22] transformed into different polytypes, for example $(5 \mathrm{H})$ with $3-\delta=2.74$ [25], or $(12 \mathrm{H})$ with $3-\delta=2.6$ [26], while it lost oxygen with temperature increase or oxygen pressure decrease.

Another phase found to exist in this system in the temperature range $1063-1323 \mathrm{~K}$ was $\mathrm{Ba}_{2} \mathrm{CoO}_{4}[22,29]$ with the monoclinic structure $a=5.8878(4) \quad \AA$; $b=7.6158(6) \quad \AA ; \quad c=10.3916(8) \quad \AA$; $\beta=90.738(2)$ [29].

This paper focuses on the phase equilibria in the $\mathrm{Y}-\mathrm{Ba}-\mathrm{Co}-\mathrm{O}$ system at $1373 \mathrm{~K}$ in air and determination of the crystal structure of intermediate phases. Since the properties of the intermediate phases strongly depend on the oxygen content the changes of $\delta$ as a function of temperature were measured.

\section{Experimental}

The samples were prepared using a conventional ceramic and glycerol-nitrate techniques. In both methods yttrium oxide $\mathrm{Y}_{2} \mathrm{O}_{3}$ (with 99.99\% purity), barium carbonate $\mathrm{BaCO}_{3}$ and cobalt oxide $\mathrm{CO}_{3} \mathrm{O}_{4}$ (both of "pure for analysis" grade) and metallic cobalt were used as starting materials. Metallic cobalt was obtained by reducing of cobalt oxide in the hydrogen flow at 773-873 K during $6 \mathrm{~h}$. Before weighting the starting materials (oxides and barium carbonate) were preliminary annealed in order to remove adsorbed gases and water. Solid state synthesis was performed by stages within the temperature range $1123-1373 \mathrm{~K}$ in air with intermediate grindings in the agate mortar in alcohol media. According to the glycerol nitrate technique yttrium oxide, barium carbonate and metallic cobalt taken in appropriate ratios were dissolved in nitric acid, and then glycerol in the amount needed for a complete reduction of nitrate ions was added. Then solution was dried to a viscous gel that further transformed to a powder while the temperature increasing. Finally this powder was annealed at $1373 \mathrm{~K}$ during $120-240 \mathrm{~h}$ with intermediate grindings. All samples for the phase equilibria study were quenched to room temperature with cooling rate about $500 \mathrm{~K} / \mathrm{min}$. The samples $\mathrm{YBaCo}_{2} \mathrm{O}_{5+\delta}$ and $\mathrm{BaCo}_{1-x} \mathrm{Y}_{x} \mathrm{O}_{3-\delta}$ for the structural examination were slowly cooled from $1373 \mathrm{~K}$ (cooling rate about $100 \mathrm{~K} / \mathrm{h}$ ) in air.
X-ray diffraction of quenched or slowly cooled powder samples was performed at room temperature using diffractometer DRON-6 in $\mathrm{Cu}-\mathrm{K} \alpha$ radiation $(\lambda=1.5418 \AA$ ) with pyrolytic graphite monochromator within the angle range $10^{\circ} \leq 2 \Theta \leq 120^{\circ}$ (scan step 0.02 or 0.04 with the exposure time $2-10 \mathrm{~s}$ ). The structural parameters were refined by the Rietveld profile method using the Fullprof2008 package. The changes of oxygen content in the single phase complex oxides were measured by TGA method (STA 409PC, Netzsch Gmbh). The samples were placed in the TGA cell, heated up to $1373 \mathrm{~K}$ and equilibrated in air at this temperature during $10 \mathrm{~h}$. The measurements were performed in the cooling and heating modes (cooling/heating rate $0.5-2 / \mathrm{min}$ ).

The absolute values of oxygen content were determined using two methods.

(1) Iodometric titration. While dissolving the samples in dilute hydrochloric acid containing an excess of potassium iodide the following reduction-oxidation reaction is taking place:

$2 \mathrm{Co}^{z+}+3 \times(z-2) \mathrm{I}^{-} \rightarrow 2 \mathrm{Co}^{2+}+(z-2) \mathrm{I}_{3}^{-}$

Since the oxygen content in the yttrium barium cobaltate can be linked with the mean oxidation state of cobalt ions $\mathrm{Y}^{3+} \mathrm{Ba}^{2+} \mathrm{Co}_{2}^{2.5+\delta} \mathrm{O}_{5+\delta}$, it is possible to calculate it from the certain amount of iodine released in the reaction (1).

The amount of liberated iodine was determined by a titration with the sodium thiosulfate:

$\mathrm{I}_{3}^{-}+2 \mathrm{~S}_{2} \mathrm{O}_{3}^{2-} \rightarrow 3 \mathrm{I}^{-}+\mathrm{S}_{4} \mathrm{O}_{6}^{2-}$

The concentration of $\mathrm{Na}_{2} \mathrm{~S}_{2} \mathrm{O}_{3}$ was preliminary determined by a chromatometric titration using exact amount of $\mathrm{K}_{2} \mathrm{Cr}_{2} \mathrm{O}_{7}$. In all cases the end points were obtained by using the automatic titration device (Akvilon ATP-02).

(2) Direct reduction of the samples in the TG cell by hydrogen $\left(10 \% \mathrm{H}_{2}-90 \% \mathrm{Ar}\right.$ ) at $1373 \mathrm{~K}$ assuming $\mathrm{Y}_{2} \mathrm{O}_{3}, \mathrm{BaO}$ and metallic $\mathrm{Co}$ as final products.

Thermal expansion measurements were carried out within the temperature range $298-1373 \mathrm{~K}$ in air using the dilatometer (Netzsch Gmbh DIL 402C) at a heating/cooling rate of $5^{\circ} \mathrm{K} / \mathrm{min}$. The samples for the measurements were preliminary sintered into the form of the bar with the sizes about $3 \times 3 \times 25 \mathrm{~mm}$ at $1100^{\circ} \mathrm{C}$ during $20 \mathrm{~h}$

\section{Results and discussion}

Phase equilibria in the $\mathrm{Y}-\mathrm{Ba}-\mathrm{Co}-\mathrm{O}$ system were systematically studied at $1373 \mathrm{~K}$ in air.

\section{1. "YCoO ${ }_{3-\delta} "-\mathrm{BaCoO}_{3-\delta}$ system}

In order to study the nature of phases existing within the compositional range $\mathrm{Y}_{1-x} \mathrm{Ba}_{x} \mathrm{CoO}_{3-\delta}(0 \leq x \leq 1)$ the samples of appropriate compositions ( $x=0,0.3,0.5,0.66,0.8,0.9$ and 1$)$ were prepared using standard ceramic and glycerol-nitrate techniques. According to the results of XRD the sample with $x=0$ consisted of $\mathrm{Y}_{2} \mathrm{O}_{3}$ and $\mathrm{CoO}$ as expected since $\mathrm{YCoO}_{3-\delta}$ is usually prepared and investigated at temperatures that do not exceed $1173 \mathrm{~K}$ [13-17]. On the other side the sample with $x=1$ was single phase $\mathrm{BaCoO}_{3-\delta}$ crystallized in hexagonal structure with the unit cell parameters $a=5.665 \AA$, $c=28.493 \AA$ (sp. gr. $P 6_{3} / m_{m}$ ) that was in good agreement with the results reported earlier [26]. The only intermediate phase formed in the $\mathrm{Y}_{1-x} \mathrm{Ba}_{x} \mathrm{CoO}_{3-\delta}(0<x<1)$ system was $\mathrm{YBaCo}_{2} \mathrm{O}_{5+\delta}(x=0.5)$. All other samples were three phase mixtures consisted of: $\mathrm{Y}_{2} \mathrm{O}_{3}$, 
$\mathrm{YBaCo}_{4} \mathrm{O}_{7+\delta}$ and $\mathrm{YBaCo}_{2} \mathrm{O}_{5+\delta}$ for $x=0.3 ; \mathrm{YBaCo}_{4} \mathrm{O}_{7+\delta}, \mathrm{YBaCo}_{2} \mathrm{O}_{5+\delta}$ and $\mathrm{BaCo}_{1-y} \mathrm{Y}_{y} \mathrm{O}_{3-\delta}$ with fixed composition $\mathrm{y}$, (which will be described below) for $x=0.66$ and 0.8 ; same $\mathrm{BaCo}_{1-y} \mathrm{Y}_{y} \mathrm{O}_{3-\delta}$ (with fixed composition), $\mathrm{YBaCO}_{4} \mathrm{O}_{7+\delta}$ and $\mathrm{BaCoO}_{3-\delta}$ for $x=0.9$.

The values of oxygen content for the sample $\mathrm{YBaCO}_{2} \mathrm{O}_{5+\delta}$ slowly cooled to room temperature obtained from the results of iodometric titration and TGA reduction were equal to $(5+\delta)=$ $5.40 \pm 0.01$ and $(5+\delta)=5.41 \pm 0.05$, correspondingly. Obtained results perfectly coincide with each other and were in good agreement with the value reported by Kim et al. [1]. The values of oxygen content in the $\mathrm{YBaCo}_{2} \mathrm{O}_{5+\delta}$ versus temperature within the range $300-1323 \mathrm{~K}$ in air calculated from the TGA measurements varied from 5.41 to 5.04 (Fig. 1).

Fig. 2 demonstrates XRD patterns of the single phase $\mathrm{YBaCO}_{2} \mathrm{O}_{5.4}$. It was found to be tetragonal with the $3 a_{p} \times 3 a_{p} \times 2 a_{p}$ superstructure

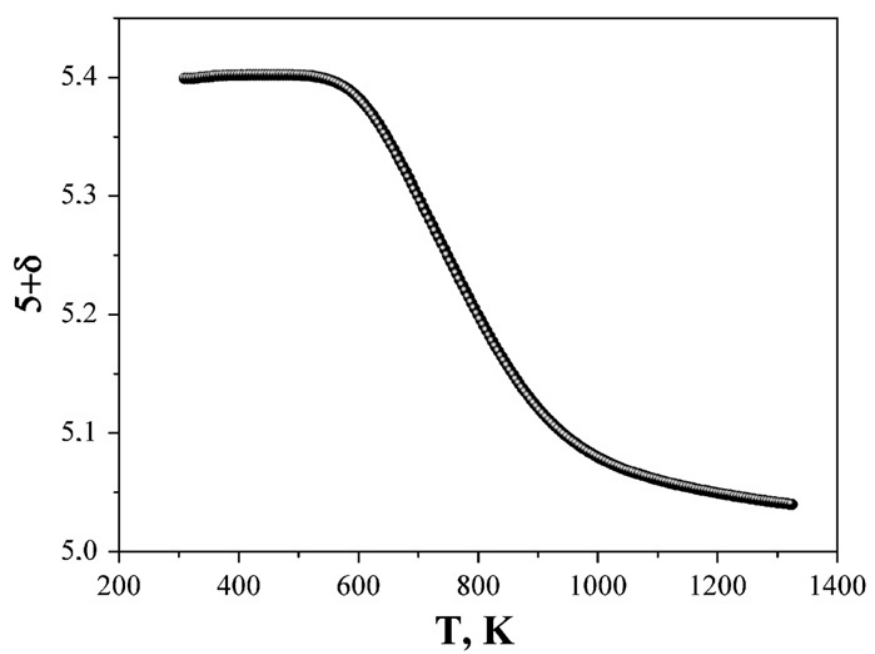

Fig. 1. Temperature dependence of oxygen content in the $\mathrm{YBaCo}_{2} \mathrm{O}_{5+\delta}$ obtained by TGA.
(P4/mmm space group, $a=11.616(1) \AA \AA, c=7.494(1) \AA)$, that is in good agreement with the data presented earlier $[2,6]$.

High-temperature X-ray diffraction patterns for the $\mathrm{YBaCO}_{2} \mathrm{O}_{5+\delta}$ in the temperature range from $298 \mathrm{~K}$ up to $1073 \mathrm{~K}$ and $\mathrm{PO}_{2}=0.21$ atm are shown on Fig.3. The results of the Rietveld refinement for the yttrium barium cobaltite $\mathrm{YBaCo}_{2} \mathrm{O}_{5+\delta}$ are presented in Table 1 . Although the changes of oxygen content were significant no structural changes were observed in $\mathrm{YBaCo}_{2} \mathrm{O}_{5+\delta}$ within the temperature range studied.

Fig. 4 presents linear increase of the unit cell parameters and unit cell volume for the $\mathrm{YBaCO}_{2} \mathrm{O}_{5+\delta}$ sample with increasing temperature in air.

The relative thermal expansion $\left(\Delta L / L_{0}\right)$ of the $\mathrm{YBaCo}_{2} \mathrm{O}_{5+\delta}$ ceramic sample also increases practically linearly with increasing temperature in the temperature range of $298-1273 \mathrm{~K}$. The average thermal expansion coefficient (TEC) of double perovskite in the measured temperature range is about $13.8 \times 10^{-6}, \mathrm{~K}^{-1}$, which is close to the value reported by Liu [3].

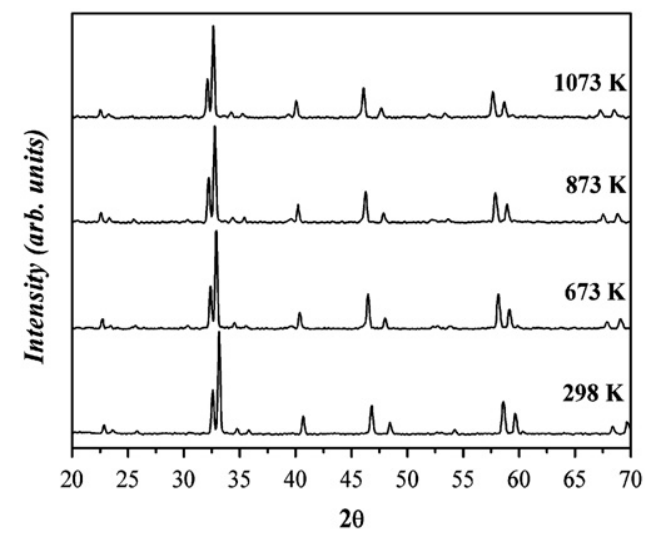

Fig. 3. X-ray diffraction pattern of $\mathrm{YBaCO}_{2} \mathrm{O}_{5+\delta}$ oxide at different temperatures.

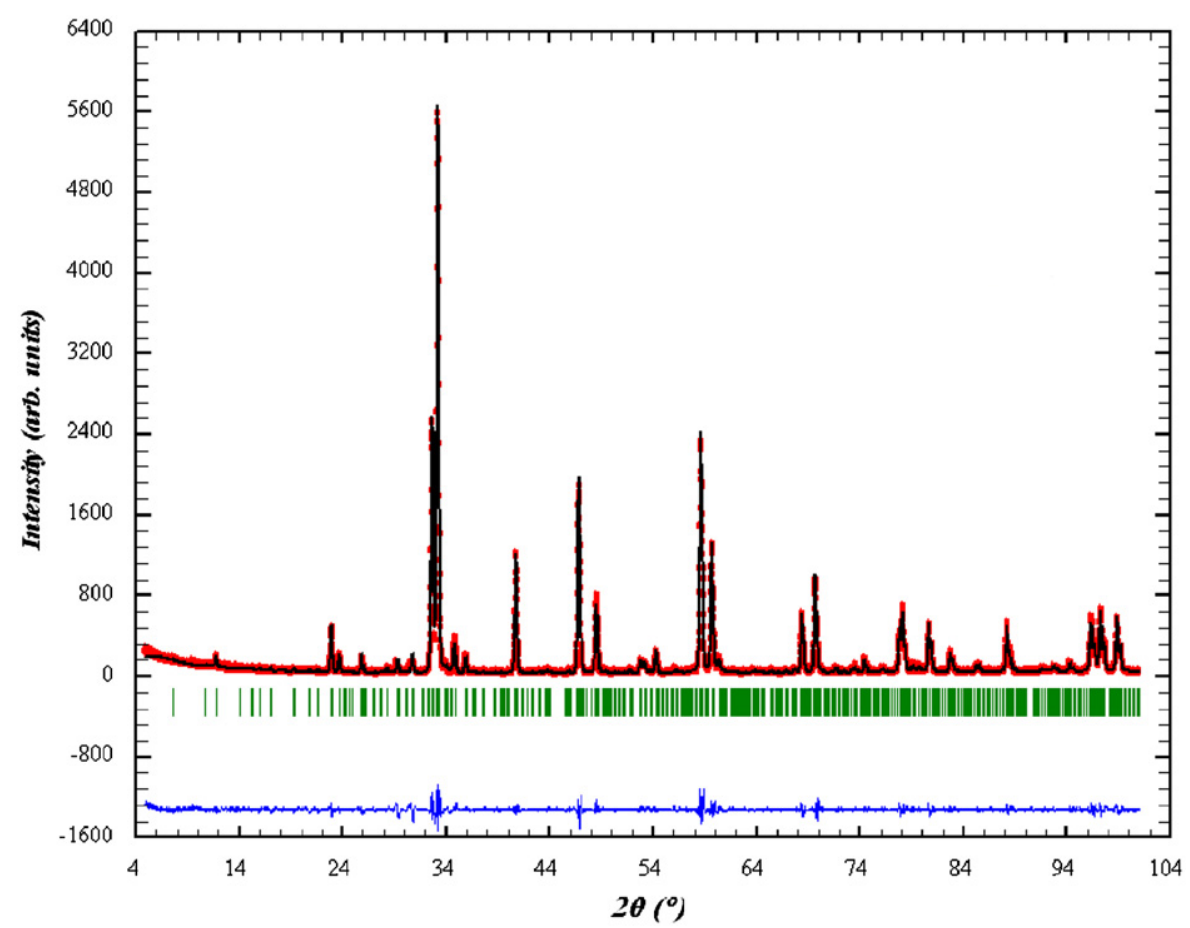

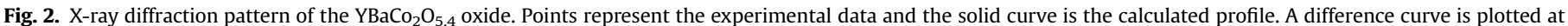
the bottom. Vertical marks represent the position of allowed Bragg reflections. 


\section{2. $\mathrm{YBaCo}_{4} \mathrm{O}_{7}$}

Complex oxide with the composition $\mathrm{YBaCo}_{4} \mathrm{O}_{7}$ was synthesized by the standard ceramic technique. According to the results of XRD analysis the sample quenched from the $1373 \mathrm{~K}$ to room temperature was single phase. XRD pattern for the $\mathrm{YBaCo}_{4} \mathrm{O}_{7}$ refined by the Rietveld method is shown in Fig. 5. The parameters

Table 1

The unit cell parameters and reliability factors for the $\mathrm{YBaCo}_{2} \mathrm{O}_{5+\delta}$ within temperature range $298 \leq \mathrm{T}, \mathrm{K} \leq 1073$ (Space group: $\mathrm{P} 4 / \mathrm{mmm}$ ).

\begin{tabular}{lcccccc}
\hline$T, K$ & $a, \AA$ & $c, \AA$ & $V,(\AA)^{3}$ & $R_{\mathrm{Br}}, \%$ & $R_{f}, \%$ & $R_{p}, \%$ \\
\hline 298 & $11.629(1)$ & $7.503(1)$ & $1014.75(3)$ & 1.34 & 2.03 & 8.80 \\
673 & $11.703(1)$ & $7.567(1)$ & $1036.45(1)$ & 2.04 & 3.14 & 12.50 \\
873 & $11.750(1)$ & $7.585(1)$ & $1047.31(1)$ & 1.66 & 3.06 & 10.90 \\
1073 & $11.791(1)$ & $7.617(1)$ & $1059.01(2)$ & 2.17 & 2.58 & 12.20 \\
\hline
\end{tabular}

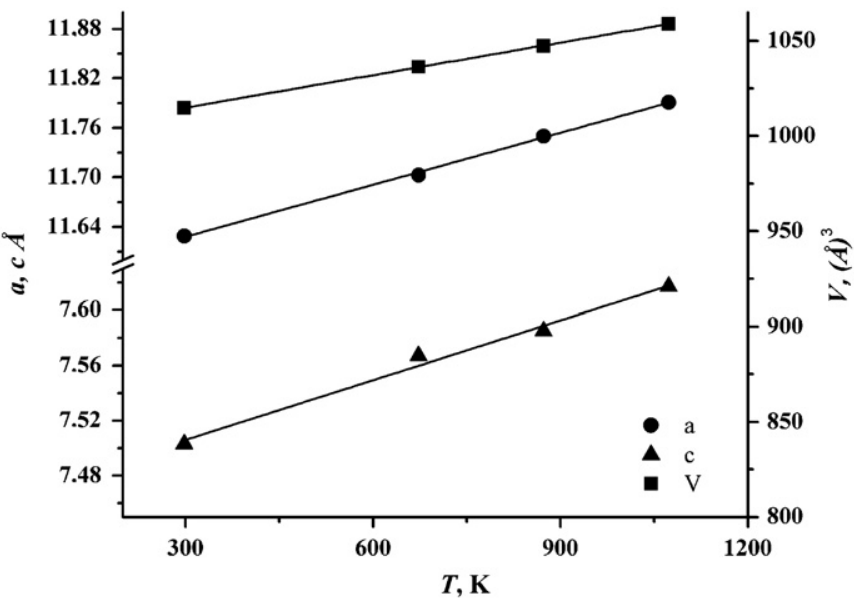

Fig. 4. Temperature dependences of the unit cell parameters for the $\mathrm{YBaCO}_{2} \mathrm{O}_{5+\delta}$ sample in air. of hexagonal unit cell: $a=6.299(1) \AA, c=10.240(1) \AA$ (sp. gr. $P 6_{3} m c$ ) are in good agreement with those reported by Tsipis et al. [5]. The refined atom coordinates are listed in the Table 2.

\section{3. $\mathrm{BaCo}_{1-y} \mathrm{Y}_{y} \mathrm{O}_{3-\delta}$ system}

According to Lomakov et al. [30] cobalt ions can be substituted by yttrium in $\mathrm{BaCoO}_{3-\delta}$. We have checked the possibility of $\mathrm{BaCo}_{1-y}$ $\mathrm{Y}_{y} \mathrm{O}_{3-\delta}$ phases formation at $1373 \mathrm{~K}$ in air. Thereto the samples within the composition range $0.0 \leq y \leq 0.6$ with the step 0.1 were prepared using standard ceramic technique described in Section 2.

According to the results of $\mathrm{X}$-ray diffraction analysis the homogeneity range for the $\mathrm{BaCo}_{1-y} \mathrm{Y}_{y} \mathrm{O}_{3-\delta}$ solid solutions at studied conditions appears within $0.1 \leq y \leq 0.4$ (Fig. 6). XRD pattern for all single phase samples were refined by Rietveld method within the cubic structure ( $\mathrm{Pm} 3 \mathrm{~m}$ space group). As an example, Fig. 7 illustrates the results for the $\mathrm{BaCo}_{0.8} \mathrm{Y}_{0.2} \mathrm{O}_{3-\delta}$ oxide, and the values of the unit cell parameters for all single phase samples are listed in Table 3.

Fig. 8 shows the linear dependency of unit cell parameters of the $\mathrm{BaCo}_{1-y} \mathrm{Y}_{y} \mathrm{O}_{3-\delta}$ solid solutions obtained in the present work and by Lomakov et al. [30] versus yttrium content.

The refined unit cell parameters and unit cell volumes of Ba$\mathrm{Co}_{1-y} \mathrm{Y}_{y} \mathrm{O}_{3-\delta}$ were increased with the increase of yttrium content probably due to larger ionic radius of $\mathrm{Y}^{3+}$ compared to that of $\mathrm{Co}^{2+} / \mathrm{Co}^{3+}$. The samples of the nominal composition $\mathrm{BaCo}_{1-y} \mathrm{Y}_{y} \mathrm{O}_{3-\delta}$ with yttrium contents $0.4<y \leq 0.6$ consisted of three phases: saturated by yttrium $\mathrm{BaCo}_{1-y} \mathrm{Y}_{y} \mathrm{O}_{3-\delta}$ solid solution, $\mathrm{Ba}_{2} \mathrm{CoO}_{4}$ and $\mathrm{BaY}_{2} \mathrm{O}_{4}$. The boundaries of the $\mathrm{BaCo}_{1-y} \mathrm{Y}_{\mathrm{y}} \mathrm{O}_{3-\delta}$ solid solution (limiting compositions of Y-poor and Y-rich $\mathrm{BaCo}_{1-y} \mathrm{Y}_{\mathrm{y}} \mathrm{O}_{3-\delta}$ solid solutions) were adjusted by the refinement of their unit cell parameters from the different multiphase samples in a vicinity of the limiting compositions using extrapolation in Fig. 8. This procedure yield the homogeneity range of $\mathrm{BaCo}_{1-y} \mathrm{Y}_{\mathrm{y}} \mathrm{O}_{3-\delta}$ as $(0.09 \pm 0.01) \leq y \leq(0.42 \pm 0.01)$.

The changes of oxygen content in the $\mathrm{BaCo}_{1-y} \mathrm{Y}_{y} \mathrm{O}_{3-\delta}$ solid solutions with $0.1 \leq y \leq 0.4$ were measured by means of thermogravimetric technique within the temperature range $298-1373 \mathrm{~K}$

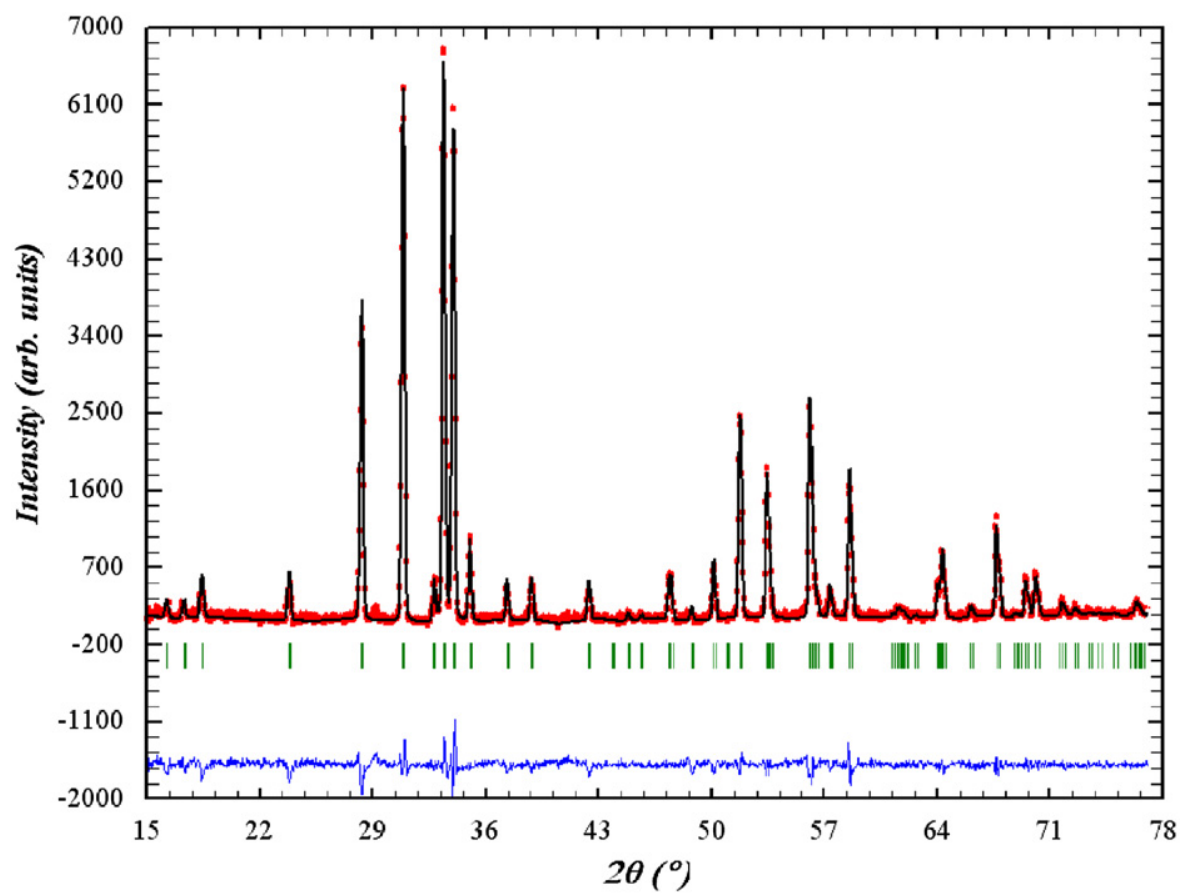

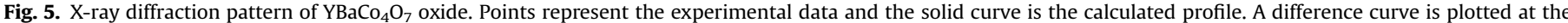
bottom. Vertical marks represent the position of allowed Bragg reflections. 
in air. The absolute values of oxygen content were determined using both methods: iodometric titration of the slowly cooled samples and reduction in the TGA cell by hydrogen. Results obtained in a number of parallel experiments by both methods were in good agreement. For example, the value of oxygen content for $\mathrm{BaCo}_{0.8} \mathrm{Y}_{0.2} \mathrm{O}_{3-\delta}$ determined by the TGA was equal to $2.530 \pm 0.005$ and that obtained by iodometric titration $-2.50 \pm 0.04$.

Temperature dependencies of the oxygen content in the Ba$\mathrm{Co}_{1-y} \mathrm{Y}_{y} \mathrm{O}_{3-\delta}$ single phase samples are shown in the Fig. 9.

The shape of the dependencies for the samples with $y=0.1$ and 0.2 are similar to each other but differ from those for the samples with

Table 2

Refined atomic coordinates and reliability factors for the $\mathrm{YBaCo}_{4} \mathrm{O}_{7}$. (sp. gr. $P 6_{3} m c$ ).

\begin{tabular}{cccccccc}
\hline Atom & $\mathrm{Y}$ & $\mathrm{Ba}$ & $\mathrm{Co} 1$ & \multicolumn{1}{c}{$\mathrm{Co}_{2}$} & $\mathrm{O} 1$ & $\mathrm{O} 2$ & $\mathrm{O} 3$ \\
\hline$x$ & 0.6667 & 0.6667 & 0.0000 & $0.1720(1)$ & $0.5130(1)$ & 0.0000 & $0.1680(1)$ \\
$y$ & 0.3333 & 0.3333 & 0.0000 & $0.8280(1)$ & $0.4870(1)$ & 0.0000 & $0.8320(1)$ \\
$z$ & 0.8700 & 0.5000 & $0.4310(1)$ & $0.6880(1)$ & $0.7430(1)$ & 0.2430 & $0.5040(1)$ \\
\multicolumn{7}{c}{$R_{\mathrm{Br}}=1.06 \%}$, & $R_{f}=2.18 \%, R_{p}=5.5 \%$ \\
\hline
\end{tabular}

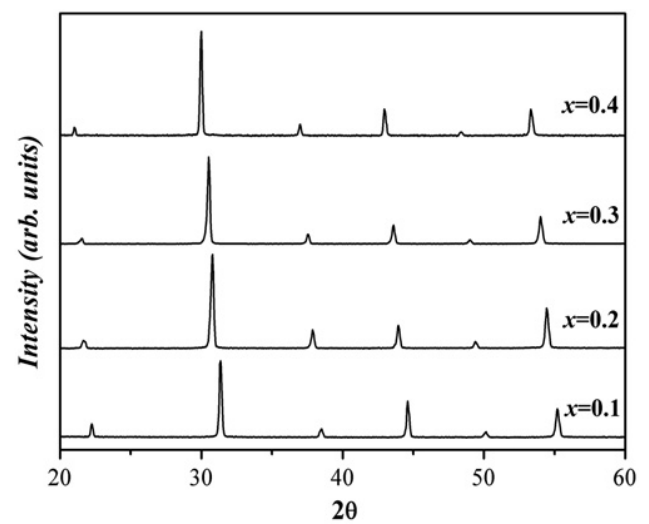

Fig. 6. X-ray diffraction pattern of $\mathrm{BaCo}_{1-y} \mathrm{Y}_{y} \mathrm{O}_{3-\delta}$ solid solutions. $y=0.3$ and 0.4 (which in turn were similar to each other as well), especially at temperature higher than $\sim 600 \mathrm{~K}$. However all curves reveal bends at temperatures about 590 and $790-820 \mathrm{~K}$. The nature of first bend for the temperature dependencies of oxygen content can be explained as starting of oxygen exchange between gaseous phase and

Table 3

Unit cell parameters and reliability factors for the $\mathrm{BaCo}_{1-y} \mathrm{Y}_{\mathrm{y}} \mathrm{O}_{3-\delta}$ solid solutions (space group: $\mathrm{Pm} 3 \mathrm{~m}$ ).

\begin{tabular}{lccccr}
\hline $\mathrm{y}$ & $a, \AA$ & $V,(\AA)^{3}$ & $R_{B r}, \%$ & $R_{f}, \%$ & $R_{p}, \%$ \\
\hline 0.1 & $4.106(1)$ & $69.23(1)$ & 1.44 & 1.24 & 14.70 \\
0.15 & $4.123(1)$ & $70.09(1)$ & 0.65 & 0.51 & 8.69 \\
0.2 & $4.136(1)$ & $70.76(1)$ & 1.76 & 1.60 & 10.10 \\
0.3 & $4.168(1)$ & $72.41(1)$ & 0.93 & 1.23 & 9.25 \\
0.4 & $4.195(1)$ & $73.85(1)$ & 0.87 & 1.59 & 11.30 \\
\hline
\end{tabular}

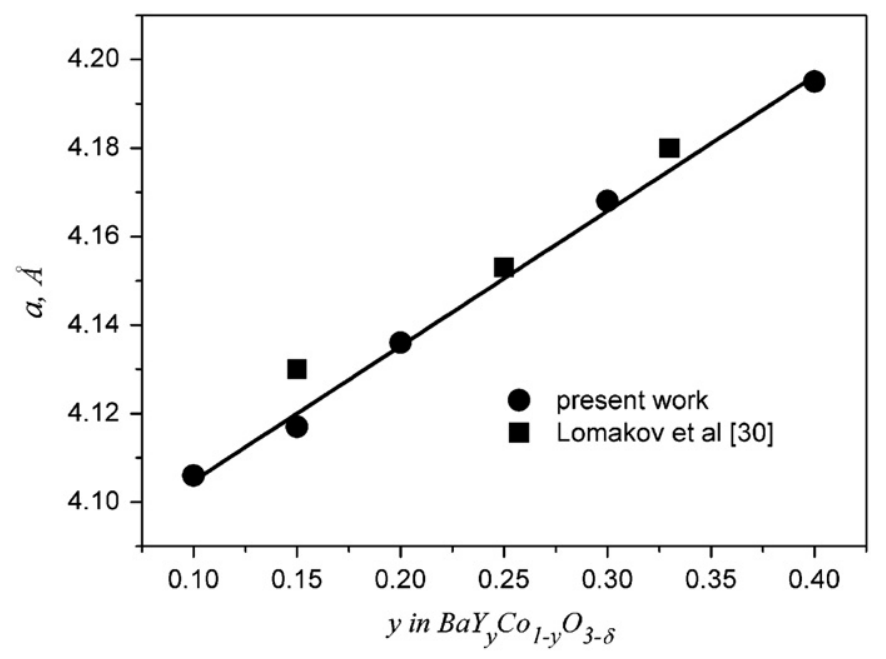

Fig. 8. The dependence of the unit cell parameters for the $\mathrm{BaCo}_{1-y} \mathrm{Y}_{\mathrm{y}} \mathrm{O}_{3-\delta}$ solid solutions versus yttrium content.

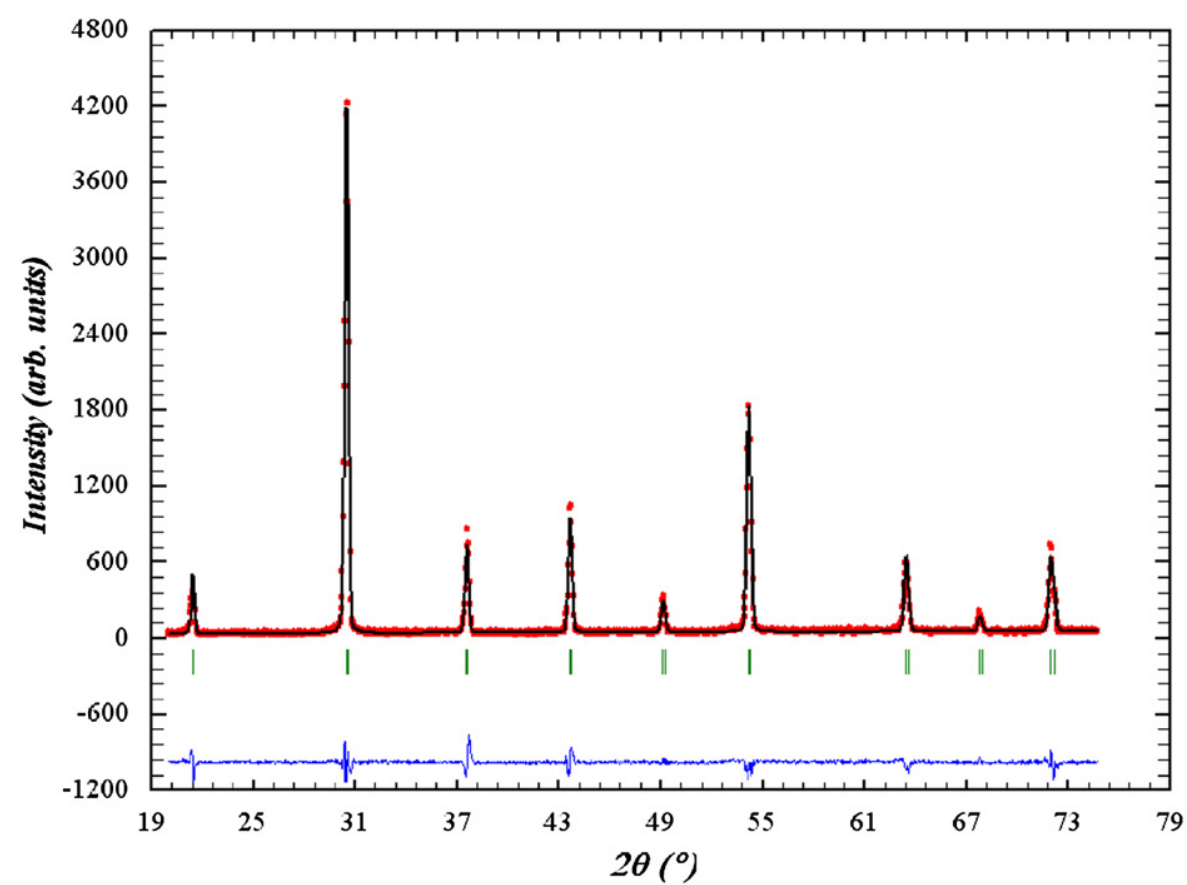

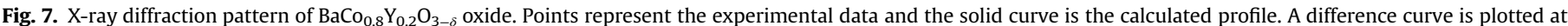
the bottom. Vertical marks represent the position of allowed Bragg reflections. 


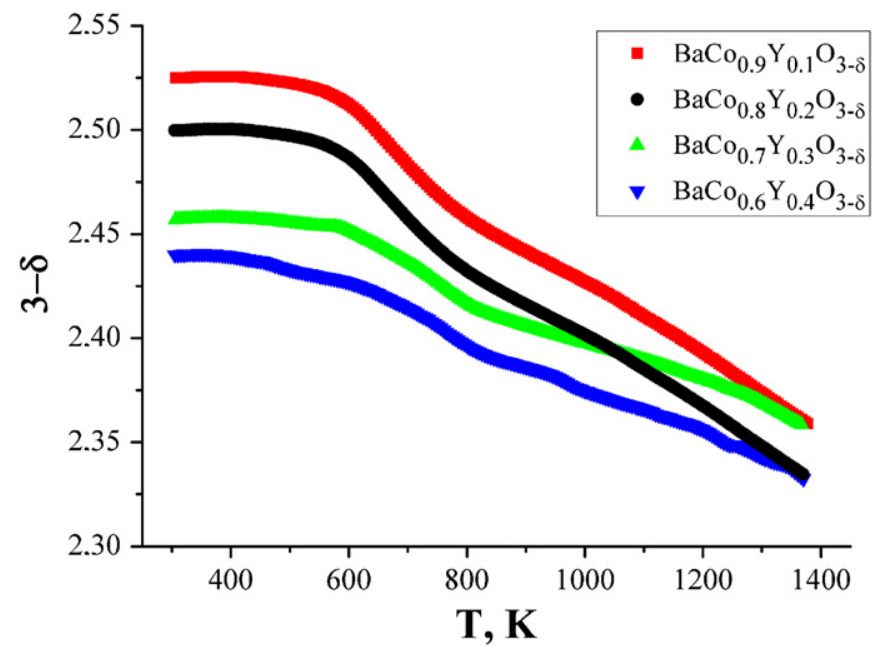

Fig. 9. Oxygen content in the $\mathrm{BaCo}_{1-y} \mathrm{Y}_{\mathrm{y}} \mathrm{O}_{3-\delta}(y=0.1 ; 0.3 ; 0.4)$ samples versus temperature in air.

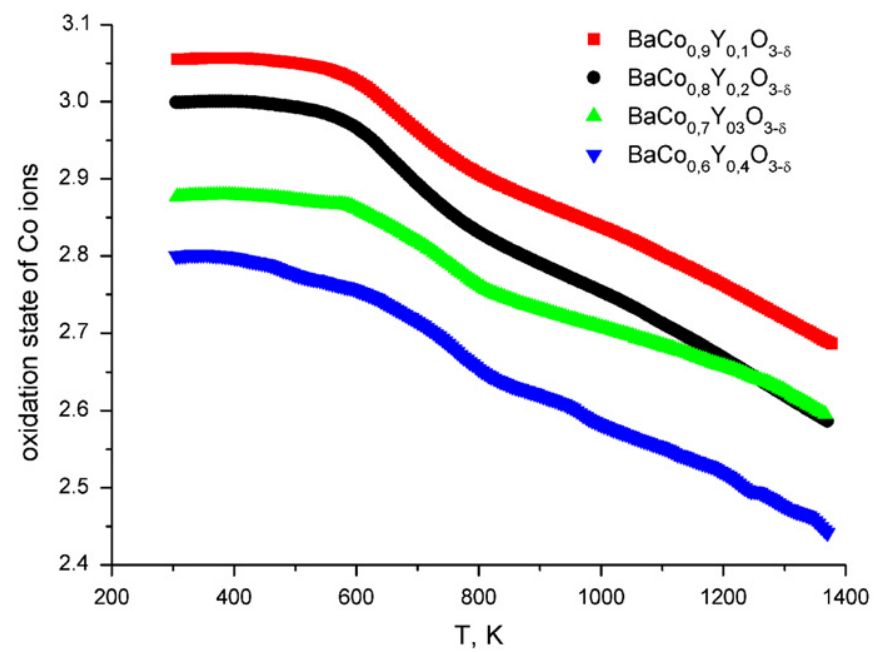

Fig. 10. Mean oxidation state of $\mathrm{Co}$ ions in the $\mathrm{BaCo}_{1-y} \mathrm{Y}_{\mathrm{y}} \mathrm{O}_{3-\delta}(y=0.1 ; 0.3 ; 0.4)$ samples versus temperature in air.

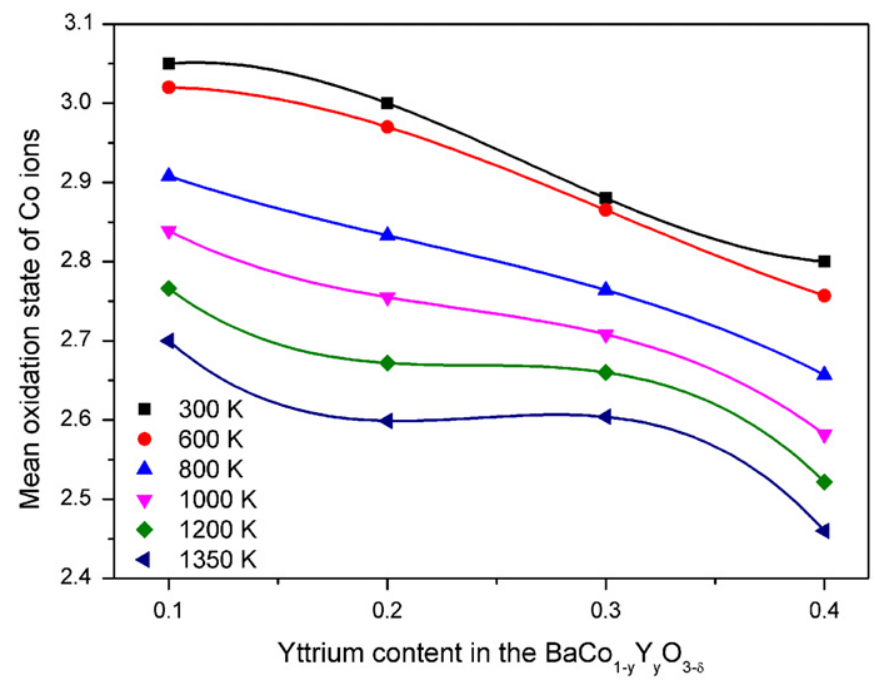

Fig. 11. Mean oxidation state of $\mathrm{Co}$ ions in the $\mathrm{BaCo}_{1-y} \mathrm{Y}_{y} \mathrm{O}_{3-\delta}$ versus yttrium content. the crystal lattice. The nature of the second bend is not so obvious, but probably connected with a peculiarity of crystal structure changes with the oxygen content variations. It is also obvious that if at temperature below $600 \mathrm{~K}$ the values of oxygen content steadily decrease while the yttrium amount increases this dependency disappears at temperatures higher than $1100 \mathrm{~K}$. However the values of mean oxidation state of Co ions versus temperature (Fig. 10), calculated from the electroneutrality conditions using the values of oxygen content look more consistent with respect to the changes of Y content. Another interesting observation of these data can be presented as the isothermal dependencies of mean oxidation state of $\mathrm{Co}$ ions versus $\mathrm{Y}$ content in the $\mathrm{BaCo}_{1-y} \mathrm{Y}_{y} \mathrm{O}_{3-\delta}$ (Fig. 11). One can see that at high temperatures (1200-1350 K) in the middle part of homogeneity range an increase of the $\mathrm{Y}$ content does not lead to the changes in oxidation state of Co ions, but is compensated by the variations in oxygen content.

Thermal expansion of $\mathrm{BaCo}_{1-y} \mathrm{Y}_{y} \mathrm{O}_{3-\delta}(y=0.0 ; 0.1 ; 0.2 ; 0.3)$ samples was studied within the temperature range $298-1200 \mathrm{~K}$ in air (Fig. 12).

Monotonous shape of $\Delta L / L=f(T)$ curves proves absence of phase transitions within studied temperature range in air. The break at $1200 \mathrm{~K}$ is observed on thermal expansion curve of $\mathrm{BaCoO}_{3-\delta}$ sample, which could be associated with structural changes.

The average TEC values for $\mathrm{BaCo}_{1-y} \mathrm{Y}_{y} \mathrm{O}_{3-\delta}$ are given in Table 4 . It is seen that TEC values decreased with increasing of yttrium content. This tendency can probably be explained by the decrease of cobalt content that causes the decrease of the oxygen exchange capacity of the samples (Fig. 9).

\subsection{Phase equilibria in the $\mathrm{Y}-\mathrm{Ba}-\mathrm{Co}-\mathrm{O}$ system}

Overall phase equilibria in the $\mathrm{Y}-\mathrm{Ba}-\mathrm{Co}-\mathrm{O}$ system were analyzed based on the results of XRD of 50 quenched samples.

Phase relations at fixed temperature and oxygen pressure in a quaternary system ( $\mathrm{Y}-\mathrm{Ba}-\mathrm{Co}-\mathrm{O}$ ) can be represented using a tetrahedron. A more convenient, planar representation can be obtained using the method of cross-sections. This method, however, is inapplicable to the system under consideration because the oxidation states of cobalt ions that various coexisted phases contain vary at the studied conditions, therefore the compositions of simple oxides and the compositions of the products do not lie in the same plane. For this reason, we used projection onto the plane of metallic components, an approach often used to represent such systems. In this respect the composition in the phase triangles is represented by the mole fraction of metallic components, for example $\xi_{\mathrm{Co}}=n_{\mathrm{Co}} /\left(n_{\mathrm{Y}}+n_{\mathrm{Co}}+n_{\mathrm{Ba}}\right)$. The oxygen content of condensed phases in each point of a projection is assumed to be equal to the thermodynamically equilibrium value and could not be calculated from the composition triangle. The compositions of the samples taken into account are represented as points in the phase diagram (Fig. 13). As a result the phase triangle for the $\mathrm{Y}$-Ba -Co-O system was divided into 14 fields.

Although we have not performed detailed systematic reinvestigation of phase equilibria in the $\mathrm{BaO}-\mathrm{Y}_{2} \mathrm{O}_{3}$ system a number of samples were prepared in order to check the existence of phases described earlier [20-22]. X-ray diffraction of quenched from the $1100^{\circ} \mathrm{C}$ Y-rich samples $\left(\xi_{\mathrm{Y}}>0.6\right)$ confirmed the existence of $\mathrm{Y}_{2} \mathrm{BaO}_{4}$ phase. Since barium oxide at room temperature easily reacts with the vapor in moist atmosphere and $\mathrm{CO}_{2}$ contained in air we have performed high temperature XRD measurement for these samples. It was shown that the phase $\mathrm{Y}_{4} \mathrm{Ba}_{3} \mathrm{O}_{9}$ can be obtained at $1100^{\circ} \mathrm{C}$, while $\mathrm{Y}_{2} \mathrm{Ba}_{4} \mathrm{O}_{7}$ had not been stable at least at $1100^{\circ} \mathrm{C}$. As an example X-ray diffraction pattern for the sample with composition corresponding to the point inside the field 7 (Fig. 13) has shown in Fig. 14.

It should be noted that no systematic study of melt region has been performed in the present work. The field (14) with partially 

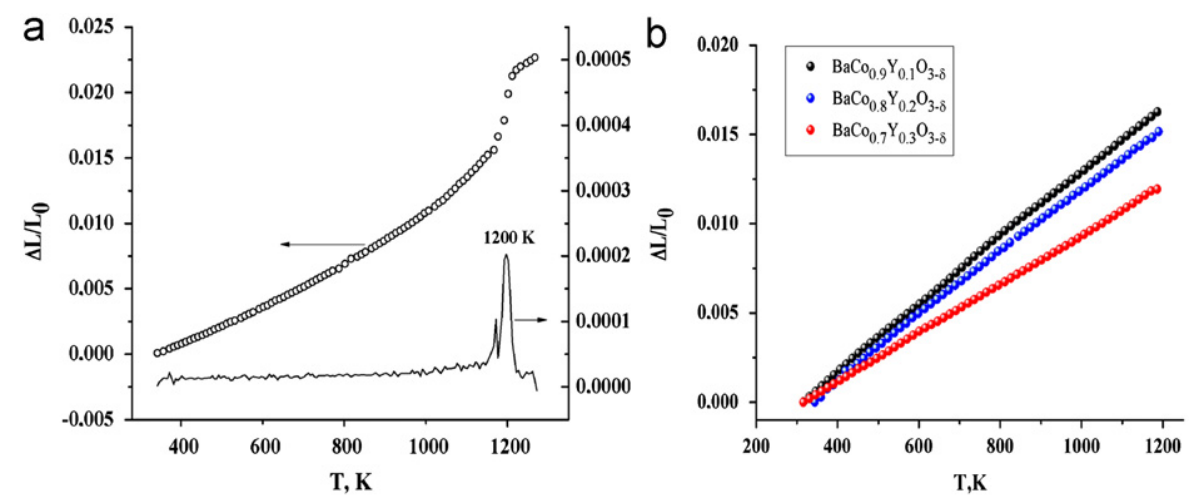

Fig. 12. Thermal expansion curves of the $\mathrm{BaCo}_{1-y} \mathrm{Y}_{y} \mathrm{O}_{3-\delta}$ samples in air: (a) $y=0.0$ (lower line corresponded to the differential curve); and (b) $y=0.1 ; 0.2 ; 0.3$.

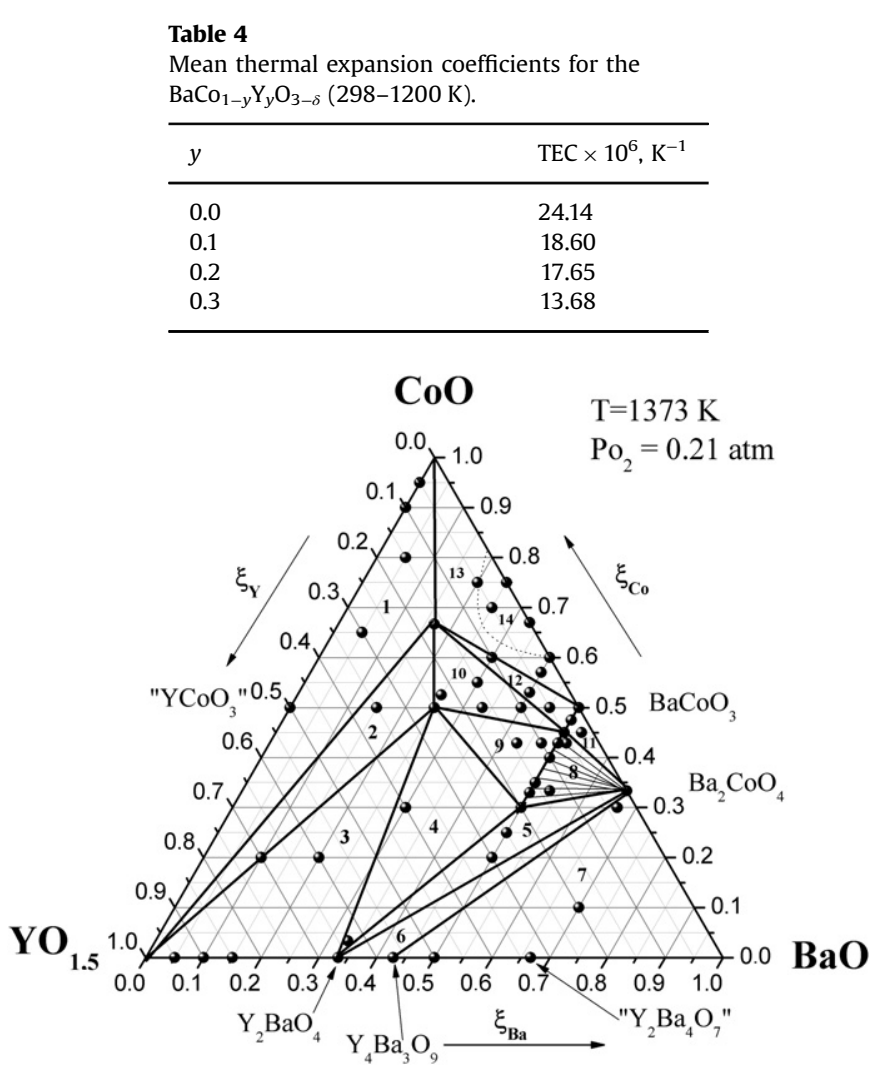

Fig. 13. A projection of isobaric isothermal phase diagram of the $\mathrm{Y}-\mathrm{Ba}-\mathrm{Co}-\mathrm{O}$ system to the metallic components triangle $\left(T=1373 \mathrm{~K}, \mathrm{Po}_{2}=0.21 \mathrm{~atm}\right): 1-\mathrm{Y}_{2} \mathrm{O}_{3}$, $\mathrm{CoO}$ and $\mathrm{YBaCo}_{4} \mathrm{O}_{7} ; 2-\mathrm{Y}_{2} \mathrm{O}_{3}, \mathrm{YBaCo}_{4} \mathrm{O}_{7}$ and $\mathrm{YBaCo}_{2} \mathrm{O}_{5+\delta} ; 3-\mathrm{Y}_{2} \mathrm{BaO}_{4}, \mathrm{Y}_{2} \mathrm{O}_{3}$ and $\mathrm{YBaCo}_{2} \mathrm{O}_{5+\delta} ; 4-\mathrm{Y}_{2} \mathrm{BaO}_{4}, \mathrm{YBaCo}_{2} \mathrm{O}_{5+\delta}$ and $\mathrm{BaCo}_{0.58} \mathrm{Y}_{0.42} \mathrm{O}_{3-\delta} ; 5-\mathrm{Y}_{2} \mathrm{BaO}_{4}, \mathrm{Ba}_{2} \mathrm{CoO}_{4}$ and $\mathrm{BaCo}_{0.58} \mathrm{Y}_{0.42} \mathrm{O}_{3-\delta} ; 6-\mathrm{Ba}_{2} \mathrm{CoO}_{4}, \mathrm{Y}_{2} \mathrm{BaO}_{4}$ and $\mathrm{Y}_{4} \mathrm{Ba}_{3} \mathrm{O}_{9} ; 7-\mathrm{Y}_{4} \mathrm{Ba}_{3} \mathrm{O}_{9}, \mathrm{Ba}_{2} \mathrm{CoO}_{4}$ and $\mathrm{BaO} ; 8-\mathrm{Ba}_{2} \mathrm{CoO}_{4}$ and $\mathrm{BaCo}_{1-y} \mathrm{Y}_{y} \mathrm{O}_{3-\delta}(0.09 \leq y \leq 0.42) ; 9-\mathrm{YBaCo}_{2} \mathrm{O}_{5+\delta}$ and $\mathrm{BaCo}_{1-y}$ $\mathrm{Y}_{y} \mathrm{O}_{3-\delta}(0.09 \leq y \leq 0.42) ; 10-\mathrm{YBaCo}_{2} \mathrm{O}_{5+\delta}, \quad \mathrm{YBaCo}_{4} \mathrm{O}_{7}$ and $\mathrm{BaCo}_{0.91} \mathrm{Y}_{0.09} \mathrm{O}_{3-\delta} ; 11-$ $\mathrm{Ba}_{2} \mathrm{CoO}_{4}, \quad \mathrm{BaCoO}_{3-\delta}$ and $\mathrm{BaCO}_{0.91} \mathrm{Y}_{0.09} \mathrm{O}_{3-\delta} ; 12-\mathrm{YBaCO}_{4} \mathrm{O}_{7}, \mathrm{BaCoO}_{3-\delta}$ and $\mathrm{BaCo}_{0.91} \mathrm{Y}_{0.09} \mathrm{O}_{3-\delta} ; 13-\mathrm{YBaCo}_{4} \mathrm{O}_{7}, \mathrm{CoO}$ and $\mathrm{BaCoO}_{3-\delta} ; 14-$ melt.

or completely melted samples is shown schematically in the phase triangle.

\section{Conclusions}

The phase equilibria in the $\mathrm{Y}-\mathrm{Ba}-\mathrm{Co}-\mathrm{O}$ system at $1373 \mathrm{~K}$ in air are presented in the form of isothermal isobaric projection to the compositional triangle. According to the results of XRD the intermediate phases formed in the $\mathrm{Y}-\mathrm{Ba}-\mathrm{Co}-\mathrm{O}$ system at $1373 \mathrm{~K}$

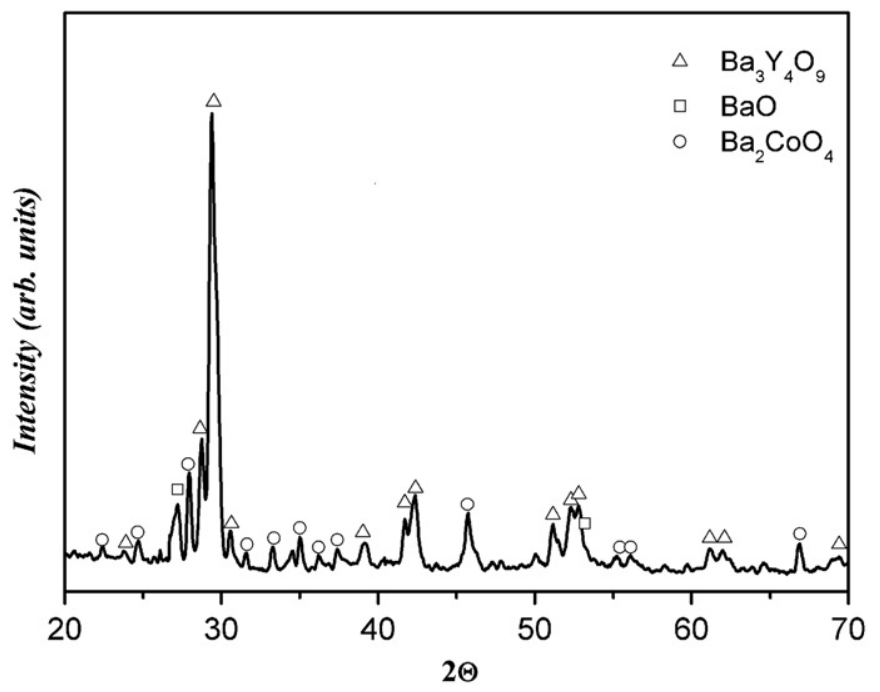

Fig. 14. XRD pattern for the sample with nominal composition: $\xi_{\mathrm{Y}}=0.2, \xi_{\mathrm{Ba}}=0.7$, $\xi_{\mathrm{Co}}=0.1$ (the point located inside the field 7 in Fig. 13).

in air were: $\mathrm{YBaCO}_{2} \mathrm{O}_{5+\delta} \quad \mathrm{YBaCO}_{4} \mathrm{O}_{7}$ and $\mathrm{BaCo}_{1-y} \mathrm{Y}_{y} \mathrm{O}_{3-\delta}$ $(0.09 \leq y \leq 0.42) . \mathrm{YBaCo}_{2} \mathrm{O}_{5+\delta}$ possesses tetragonal structure with the $3 a_{p} \times 3 a_{p} \times 2 a_{p}$ supercell (sp. gr. $P 4 / \mathrm{mmm}$ ). The value of oxygen content in the $\mathrm{YBaCo}_{2} \mathrm{O}_{5+\delta}$ has changed from 5.40 at room temperature to 5.04 at $1323 \mathrm{~K}$. The formation of $\mathrm{BaCo}_{1-y} \mathrm{Y}_{y} \mathrm{O}_{3-\delta}$ solid solution with the cubic structure (sp. gr. $\mathrm{Pm} 3 \mathrm{~m}$ ) within the compositional range $0.09 \leq y \leq 0.42$ was detected. It was shown that increasing of yttrium content leads to a gradual decreasing of oxidation state of Co ions although at relatively high temperature this decrease is not monotonous.

\section{Acknowledgments}

This work was financially supported in parts by the Russian Foundation for Basic Research (project No. 12-03-91663-ERA_a) and the Ministry for Education and Science of the Russian Federation within the Federal Target Program "Investigations and researchers on the priority directions of development for the scientific and technological complex of Russia in 2007-2013".

\section{References}

[1] J.-H. Kim, A. Manthiram, J. Electrochem. Soc. 155 (2008) B385-B390.

[2] D. Akahoshi, Y. Ueda, J. Solid State Chem. 156 (2001) 355-363.

[3] Y. Liu, J. Alloys Comp. 477 (2009) 860-862. 
[4] T. Motohashi, S. Kadota, H. Fjellvåg, M. Karppinen, H. Yamauchi, Mater. Sci. Eng. B. 148 (2008) 196-198.

[5] E.V. Tsipis, D.D. Khalyavin, S.V. Shiryaev, K.S. Redkina, P. Núñez, Mater. Chem. Phys. 92 (2005) 33-38.

6] E.V. Tsipis, V.V. Kharton, J.R. Frade, Solid State Ionics 177 (2006) 1823-1826.

[7] V. Caignaert, A. Maignan, V. Pralong, S. Hébert, D. Pelloquin, Solid State Sci. 8 (2006) 1160-1163.

[8] G. Aurelio, J. Curiale, R.D. Sánchez, Physica B. 384 (2006) 106-109.

[9] E.A. Juarez-Arellano, M. Avdeev, S Yakovlev, L. Lopez-de-la-Torre, L. Bayarjargal, B. Winkler, A. Friedrich, V.V. Kharton, J. Solid State Chem. 196 (2012) 209-216.

[10] T.V. Aksenova, L. Ya. Gavrilova, D.S. Tsvetkov, V.I. Voronin, V.A. Cherepanov, Russ. J. Phys. Chem. A 85 (3) (2011) 427-432.

[11] M. Karppinen, H. Yamauchi, S. Otani, T. Fujita, T. Motohashi, Y.-H. Huang, M. Valkeapää, H. Fjellvåg, Chem. Mater. 18 (2006) 490-494.

[12] G. Demazeau, M. Pouchard, P. Hagenmuller, J. Solid State Chem. 9 (1974) 202-209.

[13] N.B. Ivanova, S.G. Ovchinnikov, M.M. Korshunov, I.M. Eremin, N.V. Kazak, Physics-Uspekhi. 52 (2009) 789-810.

[14] K. Knížek, Z. Jirák, J. Hejtmánek, M. Veverka, M. Maryško, B.C. Hauback, H. Fjellvåg, Phys. Rev. B: Condens. Matter 73 (2006) 2144431-2144436.

[15] K. Knížek, Z. Jirák, J. Hejtmánek, M. Veverka, M. Maryško, G. Maris, T.T. M. Palstra, Eur. Phys. J. B 47 (2005) 213-220.

[16] V.G. Jadhao, R.M. Singru, G.R. Rao, D. Bahadur, C.N.R. Rao, J. Chem. Soc., Faraday Trans. 2: Mol. Chem. Phys. 71 (1975) 1885-1893.
[17] O.S. Buassi-Monroy, C.C. Luhrs, A. Chávez-Chávez, C.R. Michel, Mater. Lett. 58 (2004) 716-718.

[18] S. Uhlenbruck, F. Tietz, Mater. Sci. Eng. B 107 (2004) 277-282.

[19] L.M. Lopato, I.M. Maister, A.V. Zhevchenko, Izv. Akad. Nauk SSSR, Neorg. Mater 8 (1972) 861-864.

[20] W. Kwestroo, H. van Hal, C. Langreis, Mater. Res. Bull. 9 (1974) 1631-1637.

[21] L.M. Kovba, L.N. Lykova, E.V. Antipov, Russ. J. Inorg. Chem. 28 (1983) 724-727.

[22] T Negas, R.S Roth, Nat. Bur. Stand. Spec. Publ., Solid State Chem., Proc. 5th Mat Res. Symp. 364 (1972) 233-260.

[23] B.V. Lazarev, I.S. Shaplygin, Izv. AN SSSR. Neorgan. Mat 14 (1982) 58-60.

[24] O.V. Godgieva, N.V. Porotnikov, G.E. Nikiforova, E.A. Tishenko, Russ. J. Inorg. Chem 35 (1990) 44-48.

[25] M. Parras, A. Varela, H. Seehofer, J.M. Gonzáles-Calbet, J. Solid State Chem. 120 (1995) 327-331.

[26] A.J. Jacobson, J.L. Hutchison, An investigation of the structure of $12 \mathrm{HBaCoO} 2.6$ by electron microscopy and powder neutron diffraction, J. Solid State Chem. 35 (1980) 334-340.

[27] A. Varela, M. Parras, K. Boulahya, J.M. Gonzáles-Calbet, J. Solid State Chem. 128 (1997) 130-136.

[28] P.M. Botta, V. Pardo, C. de la Calle, D. Baldomir, J.A. Alonso, J. Rivas, J. Magn. Magn. Mater. 316 (2007) 670-673.

[29] K. Boulahya, M. Parras, A. Vegas, J. González-Calbet, Solid State Sci. 2 (2000) 57-64.

[30] M.V. Lomakov, S.Ya. Istomin, A.M. Abakumov, G. Van Tendeloo, E.V. Antipov, Solid State Ionics 179 (2008) 1885-1889. 